\title{
Coulisses
}

Revue de théâtre

19 | Hiver 1999

Varia

\section{Les yeux rouges de la culture ouvrière}

Max Alheily

\section{OpenEdition}

\section{Journals}

Édition électronique

URL : https://journals.openedition.org/coulisses/5409

DOI : $10.4000 /$ coulisses.5409

ISSN : 2546-9460

\section{Éditeur}

Presses universitaires de Franche-Comté

\section{Édition imprimée}

Date de publication : 1 janvier 1999

Pagination : 17

ISBN : 2-913322-09-3

ISSN : $1150-594 \mathrm{X}$

\section{Référence électronique}

Max Alheily, «Les yeux rouges de la culture ouvrière », Coulisses [En ligne], 19 | Hiver 1999, mis en ligne le 18 octobre 2019, consulté le 09 janvier 2022. URL : http://journals.openedition.org/coulisses/5409 ; DOI : https://doi.org/10.4000/coulisses.5409

Ce document a été généré automatiquement le 9 janvier 2022

Coulisses 


\title{
Les yeux rouges de la culture ouvrière
}

\author{
Max Alheily
}

1 C'est moi qui, ce soir-là, avait les yeux rouges à la sortie du spectacle donné au Nouveau Théâtre, tant j'étais bouleversé; à tel point que je n'ai pas souhaité en entendre « causer » après la représentation, et préféré garder pour moi tout le bonheur d'avoir retrouvé une parole perdue. Perdue pour moi, s'entend. Perdue pour le fils d'ouvrier que j'étais, celui qui, comme beaucoup de cette génération, a changé de classe sociale (oui, même si le terme n'est plus à la mode - ça fait mal ? - ça existe encore !). Et puis voilà qu'en quelques mois, Marius et Jeannette d'abord, puis Les Yeux rouges viennent me rappeler, nous rappeler que les gens modestes ont une histoire, qu'ils savent en parler, que les méchants hasards de la vie peuvent faire naître des moments d'enseignement inoubliables, que regarder le monde en face reste un acte formateur (transcendant?) pour ceux dont l'humilité est la qualité première.

2 Formidable éloge de la vie, Les Yeux rouges viennent à point pour nous réaffirmer, ou nous apprendre, qu'humilité n'est pas résignation, que c'est la conviction et le sentiment d'injustice qui font le militantisme, que le savoir-faire politique et syndical vient avec la nécessité, que ce n'est pas qu'une affaire de spécialistes... et beaucoup d'autres choses encore sur le partage, l'authenticité, l'amour, la dignité...

3 J'avais, ce soir-là, la nette sensation d'avoir assisté à quelque chose d'exemplaire: exemplaire l'idée de donner la parole à ceux qui sont trop humbles pour la prendre ; exemplaire l'attitude de l'«interviewer" face à la difficulté de parler de soi; exemplaire le travail de mise en scène (merci pour cette géniale simplicité) et celui des acteurs (là aussi, humilité et conviction ont fait des miracles); exemplaire enfin la densité de cette parole ouvrière.

4 "La musique sacrée, sans aucun doute, a fait plus de conversions que la théologie", affirmait Régis Debray à propos d'éducation politique ; il en est de même pour Les Yeux rouges en ce qui concerne la culture ouvrière qu'on a trop vite oubliée (enterrée ?) au profit du politiquement correct des « cols blancs », il ne s'agit pas ici de nostalgie mais bien de valeurs, dont on se rend compte, en écoutant les ouvrières de Lip, qu'elles sont 
plus que jamais nécessaires à la lutte pour la vie et contre le négativisme du néolibéralisme.

5 Ce soir-là, bien qu'elle ait les yeux rouges, la classe ouvrière souriait... 